УДК 343.13

DOI https://doi.org/10.32849/2663-5313/2020.2.55

\title{
Юлія Циганюк,
}

канд. юрид.наук,

завідувач кафедри права та правоохоронної діяльності

Хмельницького інституту

Міжрегіональної Академії управління персоналом,

адвокат, провідний юрисконсульт сектора юридичного забезпечення

Хмельницького науково-дослідного експертно-криміналістичного иентру

Міністерства внутрішніх справ Украӥни

\section{АНГЛО-АМЕРИКАНСЬКА СИСТЕМА КРИМІНАЛЬНОГО ПРОЦЕСУ}

Значний інтерес викликає аналіз нетипових для рідної країни прикладів правової практики закордонних краӥн, а особливий інтерес викликає юридична практика та джерела, на якій вона базується, що відмінні від вітчизняного кримінального прочесу. Одним із таких для українського кримінального процесу є кримінальний процес англо-американської системи кримінального процесу. Саме тому у статті приділено увагу дослідженню англо-американської системи кримінального процесу. Автором на основі загальних, а також окремих досягнень кримінальної проиесуальної науки, зокрема з використанням наукових джерел країн англо-американської правової системи, визначені особливості англоамериканської системи кримінального процесу. За основу обрано дві «класичні» країни иієї системи: Англію та Сполучені Штати Америки.

Автором визначено, що з урахуванням сучасних реалій норм кримінального прочесуального законодавства України та практики його застосування, а також за умови окремих встановлених правил кримінальна процесуальна доктрина могла би посісти своє місце у кримінальному процесі України. Також зазначено, що съогодні відбувається процес поєднання різних кримінальних процесуальних систем світу, однак англо-американська система кримінального прочесу має свої особливості, які порівняно з іншими системами кримінального процесу можна виокремити. Такими особливостями $\epsilon$ те, що джерелами кримінального процесуального права є судовий прецедент, нормативно-правові акти та правова доктрина, водночас важко визначити пріоритет прецеденту над нормативно-правовими актами у Сполучених Штатах Америки, хоча він наявний в Англії. Також англо-американська система кримінального процесу є змагальною, або обвинувальною. I однією із засадничих ознак можна назвати те, що ия система заснована на справедливості, у ній беруть початок такі явища кримінального прочесу, як угода про визнання вини, суд присяжних, конщепція відновного правосуддя, дискреційність повноважень осіб, які ведуть кримінальне судочинство тощо.

Ключові слова: система кримінального процесу, англо-американська система, прецедент, доктрина, справедливість.

Постановка проблеми. Науковий та популярний інтерес до світових систем кримінального процесу має своє раціональне значення, адже детальне вивчення досвіду або хоча б його поверхневе споглядання цікаві для всіх суспільних сфер. Значний інтерес викликає аналіз нетипових для рідної країни прикладів правової практики закордонних країн. Особливий інтерес викликає юридична практика та джерела, на якій вона базується, що відмінні від вітчизняного кримінального процесу. Одним із таких є кримінальний процес англо-американської системи кримінального процесу.

Цей процес характеризується низкою системних особливостей, дослідження яких необхідно провести як для ознайомлення, так і з метою наукового аналізу, зокрема для запозичення позитивного досвіду для перспективного правового регулювання кримінального процесу України.

Серед науковців, що досліджували вказану тему, можна виокремити таких, як: К. Арушанян, В. Бєлєнький, Г. Власова, А. Долгополов, І. Српильов, П. Маланчук, А. Молдован, Н. Нестор, М. Хворостяний, а також багато інших. Але комплексного висвітлення англо-американської системи кримінального процесу немає.

Мета статті - зробити аналіз англо-американської системи кримінального процесу.

Виклад основного матеріалу. Усім очевидно, що велика відмінність розділяє дві системи кримінальної процедури (англоамериканська та континентальна - Ю. ЦЦ.), 
розроблені західною людиною протягом останніх восьми століть. Коли компаративіст переносить увагу з континенту на англомовний світ, він бачить настільки яскраві контрасти, що розмаїття, наявне в кожній юридичній культурі, набуває великого значення. Хоча легко зазначити різницю між двома системами, набагато складніше дослідити, наскільки детально ці відмінності можна простежити до більш фундаментальних відмінностей у тому, як розуміють ці дві системи характер справедливості, порядку та самого закону. Основний контраст між цими двома системами - це той, який вказує на змагальний (або обвинувачуючий) аспект англо-американського процесу та незмагальний (або інквізиційний) характер континентального способу провадження. Ця дихотомія, як би не була витончена, не враховує безлічі важливих варіацій між двома системами [1, с. 481].

Юристам під час дослідження норм права подобається наголошувати на відмінностях англо-американської (змагальної) системи кримінального правосуддя та континентальної, чи цивільної (інквізиційної) системи. Серед юристів Сполучених Штатів Америки (далі - США) спостерігається тенденція прославляти американську систему, яка, як стверджується, є більш захищеною свободами, більш демократичною і такю, що менше домінує над органами державної влади, ніж традиції системи цивільного права, завдяки ролі присяжних, формальній рівності між представниками влади та відповідачем, «нейтральної» незалежності судової влади. Однак усе частіше академічні експерти, а також публічні коментатори прагнуть робити такі ж різкі порівняння, навпаки, вихваляючи інквізиційну систему як більш раціональну, більш ефективну та ще більш обережну, з метою уникнення засудження невинних, завдяки домінуванню професійних суддів, що мають мандат для пошуку істини, зменшення значення впливу захисників i, що особливо важливо, за відсутності угоди про визнання вини [2, с. 2117-2118]. Тут необхідно звернути увагу на те, що джерело 1998 р., а в теперішньому кримінальному процесуальному законодавстві країн Свропи угоди про визнання вини поширені.

Малкольм М. Філі зазначає, що формальним завданням системи кримінального правосуддя є розгляд арештів, визначення вини чи невинуватості, а в разі встановлення вини - визначення відповідної санкції (покарання - Ю. Ц.). Основними суб'єктами системи є підсудний, прокурор, захисник, суддя, офіцер, судовий діловод, різною мірою інші особи, як-от свідки, додатково поліція, діло- води, особи, що звільняють, дозволяють умовне звільнення, судові психіатри та соціальні працівники, сім'ї та друзі підсудних. Система здійснення правосуддя, будь то змагальна чи інквізиційна, має ключові елементи іï організації, серед яких: інституціолізована взаємодія великої кількості суб̆'єктів ролі яких чітко визначені, які зобов'язані дотримуватися правил, вони відповідальні за загальну мету - арешт особи [3, с. 407] Уважаємо, що зазначена мета автора визначається тим, що система кримінального судочинства має бути спрямована на забезпечення дотримання прав особи під час обмеження чи позбавлення ï свободи, а також призначення їй покарання.

В історії суспільства існували різні види, різновиди і форми кримінального судочинства. Більшість процесуалістів зводять їх до трьох типів кримінального процесу: обвинувального, розшукового (інквізиційного) та змішаного (слідчо-судового). Обвинувальний кримінальний процес характерний в основному для періодів рабовласницького ладу і раннього феодалізму. Автор визначила, що в цьому виді кримінального процесу значна роль належала обвинувачеві, яким була особа, що постраждала від злочину. Від волі обвинувача залежали виникнення, продовження або припинення кримінального процесу. Без його вимоги не могло початися провадження у справі. На обвинувача покладався обов'язок доказування, розшук обвинуваченого. Спір обвинувача і протилежної сторони проходив перед судом. Як докази використовувались відомості, отримані шляхом застосування насильства, у результаті поєдинку тощо. Судочинство проходило гласно й усно. Класичним зразком обвинувального (змагального) кримінального процесу є кримінальний процес Англії та США. Такий вигляд кримінальний процес мав і на території, де проживали слов'янські племена $[4$, c. 165$]$

Важливе також є дослідження кримінального процесуального досвіду США, оскільки ця держава досягла значних успіхів у розвитку державно-правових інститутів. Кримінальне процесуальне право США більш розвинене, тому більшою мірою, ніж англійське, наближене до континентальної правової системи [5, с. 36]. Коротко проаналізуємо особливості англо-американської системи кримінального процесу за зразком провідних країн цієї системи (США й Англія).

Фредерик Р. Кудера зазначив, що американські юристи, навчені традицією, уважають, що habeas corpus - це основа їхніх свобод, що Рим і Карфаген втратили своє лише тому, що вони не винайшли цього захо- 
плюючого юридичного явища. Та ці юристи зазвичай відхиляють інквізиційну систему, ставляться до неї з недовірою або висловлюють негативні епітети [6, с. 327].

Правова система СШАє досить складною і своєрідною. У ній співіснують практично на «паритетних началах» федеральна правова система і система штатів (так званий «правовий дуалізм»). Федеральне кримінальнопроцесуальне, як і все американське, право становить сукупність норм як писаного, так і неписаного права [7, с. 241]. Ускладнюе застосування будь-якої норми чи правила у США той факт, що кожний штат має своє кримінальне законодавство та кримінальний процес (процедура). У зв'язку із цим виникають суттєві розбіжності правового регулювання федерального кримінального процесу та кримінальної процедури штатів [8, с. 48].

За своєю формою кримінальний процес США є обвинувальним, або змагальним, як і в Англії, але, на відміну від неї, у США кримінально-процесуальне право частково кодифіковано, оскільки вироблені й ухвалені Конституція США і конституції штатів. У штатах (Іллінойс, Каліфорнія, Нью-Йорк та ін.) діють кримінально-процесуальні кодекси [9, с. 74].

Неписане право, яке створюють і застосовують федеральні суди, дуже поширене і має високий авторитет. Із питань тлумачення Конституції США і встановлених нею гарантій прав особи, зокрема й у кримінальному судочинстві, федеральні прецеденти мають пріоритетне значення. Найвідоміші прецеденти такі: про вилучення 3 числа доказів визнання своєї вини обвинуваченим, яке він зробив після відмови йому в побаченні із захисником (таким прецедентом стала справа Ескобедо, 1964 р.); про недопустимість використання доказів, отриманих iз порушенням установлених Конституцією США гарантій законності проведення обшуку і виїмки (прецедентом стала справа Менна, 1961 р.); про надання матеріально незабезпеченим засудженим судами штатів копій необхідних документів безоплатно, якщо засуджені мають намір оскаржити вирок (прецедент - справа Гріффіна, 1956 р.); про недопустимість використання в суді заяв обвинуваченого, якщо йому під час перебування під вартою не було роз'яснено право не відповідати на запитання, оскільки отримана інформація в подальшому може бути використана проти нього; право мати захисника і право мати безоплатного захисника, якщо він не може оплатити витрати, пов'язані із запрошенням захисника; водночас тягар доказування того, що обвинувачений відмовився від права не відповідати на запи- тання, покладено на сторону обвинувачення (найвідоміший прецедент - справа Міранди, 1966 р.) [7, c. 242].

Одним із джерел, що формує систему кримінального процесу США, $є$ кримінальна процесуальна доктрина. $Є$. Полянський зазначив, що кримінально-правова доктрина США існує на концептуальному рівні і має широке функціональне призначення, зважаючи на недостатність регулятивних можливостей законодавства, яке є фрагментарним, крім того, саме правова доктрина є тією інтегруючою силою, яка здатна утримувати разом щонайменше 53 окремі системи кримінального законодавства США [10, с. 9]. Ураховуючи сучасні реалії норм кримінального процесуального законодавства України та практики його застосування, необхідно зазначити, що за умови запровадження деяких правил кримінальна процесуальна доктрина могла би посісти своє місце у кримінальному процесі України. Але, наприклад, експертиза у сфері права прямо заборонена чинним Кримінальним процесуальним кодексом України. Хоча, на думку автора, це не $є$ прямим відображенням заборони використання доктрини кримінального процесу, однак є суттєвою перешкодою для цього. P. Вайсберг зауважив, що доктрина менш важлива для досягнення своєї передбачуваної мети - належного здійснення кримінального правосуддя, ніж це могло здаватися колись [11, с. 854].

Окремі автори визначили, що можна передбачити неминучу загибель деяких видатних учень кримінального процесу. Ці доктрини, зокрема, конституційні стандарти, що використовуються для оцінки дискреційного правопорядку у громадах, пережили свою корисність. Настав час побудувати нову кримінальну процедуру, яка унікально підходила б до умов, що нині характеризують американське суспільно-політичне життя i, ймовірно, можуть охарактеризувати іï в осяжному майбутньому [12].

Також звернемо увагу на те, що окремо автори зазначають, що саме процедура $€$ визначальною характеристикою американського кримінального процесу, ключовим елементом якої є процесуальна справедливість. Її цінність, що виникає з поваги до прав людини, ставиться вище цінності ефективності судового рішення і навіть може суперечити останній $[13$, с. 9].

Що ж до Англії, то, на думку Н. Нестор, англійська модель правосуддя полягає в наявності вибору тільки між двома традиційними варіантами реакції держави на вчинений злочин, виходячи 3 його небезпеки для суспільства. Перший варіант - це офі- 
ційне кримінальне переслідування особи, результатом якого має бути покарання як юридичний наслідок учинення злочину. Другий варіант - це відмова від кримінального переслідування особи, тобто фактично залишення порушення кримінально-правової норми без будь-якої реакції з боку держави [14, с. 145]

Г. Власова визначила, що англійський процес був суто приватно-змагальним до появи у XII ст. за Генріха II порядку розслідування через присяжних в особливо тяжких злочинах. Особливістю англійського приватно-змагального процесу був поєдинок. Авторка зазначила, що у країнах загального права приватне начало донині є вираженим і провадження має багато рис приватно-змагального типу, наприклад, угоди про визнання вини [4, с. 168].

А. Молдован визначив, що за формою англійський кримінальний процес є обвинувальним, або змагальним, тобто таким, у якому весь рух кримінального процесу спрямовується зусиллями обвинувача. Крім того, він будується на засадах змагальності, полягає в тому, що на всіх стадіях являе собою спір, боротьбу формально рівноправних сторін - обвинувача й обвинуваченого, суд же є лише арбітром у їхньому спорі (змаганні). Формально проти обвинуваченого виступає король (королева), обвинувач же, навіть якщо він $є$ потерпілим від злочину, здійснює кримінальне переслідування від імені корони. Основна турбота про збирання доказів, на підставі яких вирішується справа, покладається на сторони - обвинувача й обвинуваченого [9, с. 65].

Англійське кримінальне процесуальне право - найстаріша процесуальна консервативна система, що зумовлено історичними традиціями. Водночас воно ніколи не мало єдиного кримінального процесуального закону, який би всебічно регламентував провадження у кримінальних справах. Винятком $є$ Шотландія, для якої британський парламент у 1975 р. видав Закон про кримінальний процес. Натепер в Англії накопичилося понад 300000 судових рішень, які мають силу прецеденту. Такі рішення є обов'язковими для всіх судів під час розгляду ними аналогічних справ, хоча практично нікому, крім професійних юристів, вони не відомі. Статутне право - це 300 парламентських актів і 99 томів так званого делегованого законодавства $[15$, с. $41 ; 5$, с. 34-35]. Важливою ознакою загального права, за М. Хворостяним, виступає автономія судової влади від будь-якої іншої влади в державі, що проявляється у відсутності прокуратури й адміністративної юстиції. У даний час поряд із загальним правом у країнах англосаксонської правової сім'ї широко розвинено законодавство (статутне право), джерелом якого $є$ акти представницьких органів, що свідчить про складні процеси еволюції цієї правової сім'ї. Однак вихідні принципи організації правова система, зокрема Англії, зберігає із XIII ст. дотепер [15, с. 203].

К. Аршунян визначила, що під час розгляду кримінальних проваджень, зважаючи на їхній великий авторитет, також беруться до уваги наукові дослідження і підручники англійських юристів, які формально не мають обов'язкової сили. Отже, кримінальний процес Англії є громіздким, заплутаним і складним через архаїчність правил та інститутів, формальну дію старовинних законодавчих актів, відсутність кодифікації величезної кількості різних за обсягом і змістом джерел кримінального процесуального права [5, с. 35].

Англо-американський тип системи кримінального процесу характеризується також такими особливостями, як:

- існування суду коронера (США);

- доказове право має ознаки окремої галузі, що визначає специфіку доказування;

- система присяжних як величезного внеску у зміцнення думки людей про справедливість судів;

- інститут умовно-дострокового звільнення, коли таке звільнення надається в позасудовому порядку спеціальною комісією;

- акцент на концепції відновного правосуддя (Restorative Justice);

- широке використання угод про визнання вини;

- дискрейційність повноважень прокуpopa;

- спеціалізоване ювенальне судочинство тощо.

\section{Висновки}

Отже, можна дійти висновку, що сьогодні відбувається процес поєднання різних кримінальних процесуальних систем світу, однак англо-американська система кримінального процесу має свої особливості, а саме:

- джерелами кримінального процесуального права є судовий прецедент, нормативно-правові акти та правова доктрина, водночас важко визначити пріоритет прецеденту над нормативно-правовими актами у США, хоча він існує в Англії;

- англо-американська система кримінального процесу є змагальною, або обвинувальною;

- ця система заснована на справедливості, у ній беруть початок такі явища кримінального процесу, як угода про визнання 
вини, суд присяжних, концепція відновного правосуддя, дискреційність повноважень осіб, які ведуть кримінальне судочинство тощо.

\section{Список використаних джерел:}

1. Damaška Mirjan. Structures of Authority and Comparative Criminal Procedure. The Yale Law Journal. 1975. Vol. 84. № 3. P. 480-544. DOI: $10.2307 / 795463$.

2. Lynch Gerard E. Our Administrative System of Criminal Justice. Fordham Laze Reviеш. 1998. Vol. 66. P. 2117-2151. URL: http://ir.lawnet.fordham.edu/flr/vol66/iss6/3

3. Feeley Malcolm M. Two Models of the Criminal Justice System: An Organizational Perspective. Law E Society Review. 1973. Vol. 7. № 3. P. 407-426. DOI: $10.2307 / 3052922$.

4. Власова Г. Види кримінального процесу: історично-правові аспекти. Право $і$ безпека. 2010. № 5. C. 164-169. URL: http://nbuv.gov.ua/UJRN/ Pib 2010539

5. Арушанян К. Виконання судових рішень у кримінальному провадженні: досвід Англії та США. Науковий часопис Начіональної академії прокуратури Украӥни. 2017. № 1. С. 32-38.

6. Coudert Frederic R. French Criminal Procedure. Yale L. J. 1910. № 19. P. 326-340. URL: https://digitalcommons.law.yale.edu/ylj/ vol19/iss5/2.

7. Долгополов A. Особливості джерел кримінального процесу Франції і США. Науковий вісник Національного університету біоресурсів $i$ природокористування України. Серія «Право». 2012. Вип. 173 (3). С. 239-244.
8. Стаценко А. «Правило Міранди» як елемент міжнародного права прав людини: український досвід. Альманах міжнародного права. 2015. Вип. 8. С. 47-54.

9. Молдован А. Кримінальний процес: Україна, ФРН, Франція, Англія, США : навчальний посібник. 2-ге вид. Київ : Центр учбової літератури, 2010. 352 с.

10. Полянський $Є$. Кримінально-правова доктрина США: генезис, обгрунтування, перспективи : автореф. дис. ... докт.. юрид. наук: 12.00.08. Одеса, 2015. 36 с.

11. Weisberg Robert. Criminal Procedure Doctrine: Some Versions of the Skeptical. Journal of Criminal Law E Criminology. 1985. Vol. 76. Is. 4. P. 832-855. DOI: 0091-4169/85/7604-832.

12. Meares Tracey L., Kahan Dan M. The Coming Crisis of Criminal Procedure. Faculty Scholarship Series. 1998. URL: https://digitalcommons.law.yale. edu/fss_papers/478/.

13. Стойко Н., Семухина О. Уголовный процесс в США: учебное пособие. Краснояр. гос. ун-т. Красноярск, 2000. 315 с.

14. Нестор Н. Медіація у кримінальному процесі Сполученого Королівства Великої Британії. Бюлетень Міністерства юстищї Украӥни. 2014. № 12. C. 144-148.

15.Загурський О. Судові дебати в кримінальному процесі: правові та психологічні проблеми : дис. ... канд. юрид. наук: 12.00.09. ІваноФранківськ, 2003. 215 с.

16. Хворостяный М. Австралийская правовая система и её отличие от правовых систем других стран англосаксонской правовой семьи. Правова держава. 2009. № 11. С. 203-207. URL: http://nbuv.gov.ua/UJRN/Prav 2009 11 41C. 203.

Great interest is of the analysis of atypical examples of jurisprudence contained in the jurisprudence of foreign countries, and of particular interest is the case law and sources on which it is based, which are different from the domestic criminal process. One of those for the Ukrainian criminal trial is the criminal process of the Anglo-American criminal trial system. That is why the article focuses on the investigation of the Anglo-American criminal process. The author, based on the general as well as individual achievements of criminal procedural science, including the use of scientific sources of the countries of the Anglo-American legal system, identifies the features of the Anglo-American criminal process. Two "classic" countries of this system were chosen as the basis: England and the United States of America.

The author determines that, given the current realities of the rules of criminal procedure legislation of Ukraine and the practice of its application, and subject to certain established rules, criminal procedural doctrine could take its place in the criminal process of Ukraine. It is also noted that today there is a process of combining different criminal procedural systems of the world, but the Anglo-American criminal process system has its own peculiarities that can be distinguished in comparison with other criminal process systems. Such peculiarities are that the sources of criminal procedural law are judicial precedent, regulations and legal doctrine, while it is difficult to determine the precedent of precedent over legal acts in the United States of America, while it exists in England. Also, the Anglo-American criminal trial system is competitive or indictable. And one of the basic features is that this system is based on justice and it initiates such phenomena of the criminal process as plea agreement, jury trial, concept of restorative justice, discretionary powers of the persons conducting criminal proceedings and so on.

Key words: criminal process system, Anglo-American system, precedent, doctrine, justice. 